\title{
Nutrient and polyphenolic composition of industrial strawberry press cake
}

\author{
Michał Sójka • Elżbieta Klimczak • \\ Jakub Macierzyński $\cdot$ Krzysztof Kołodziejczyk
}

Received: 28 March 2013 / Accepted: 21 July 2013 / Published online: 9 August 2013

(C) The Author(s) 2013. This article is published with open access at Springerlink.com

\begin{abstract}
The objective of the present work was to determine the nutrient and polyphenolic composition of dried strawberry press cake (SPC), as well as that of its seedless fraction, termed exhausted strawberry flesh (ESF). The study materials were obtained over three consecutive years from an industrial facility manufacturing concentrated fruit juices. On average, SPC consists of $40 \%$ seeds, $3.5 \%$ sand, and about $55 \%$ ESF. In the dry matter of SPC and ESF, the mean content of fat is 9.8 and $3.5 \%$, protein 17.3 and $20.4 \%$, and total polyphenols 3,449 and 5,410 mg/100 g, respectively. Both materials are rich in total dietary fiber, whose content amounts to $60 \%$. The predominant polyphenols in SPC and ESF are flavanols and ellagitannins, which collectively constitute over $95 \%$ of the determined total polyphenol content. In ESF composition, of note is the high content of the strawberry ellagitannin, agrimoniin, which is approximately $1,000 \mathrm{mg} / 100 \mathrm{~g} \mathrm{DW}$ (dry weight). SPC has the disadvantage of being highly contaminated with sand $(3.4 \%)$, which accumulates in ESF (5.6\%). However, as compared to SPC, ESF contains approximately $20 \%$ more proteins and almost three times less fat. Based on our results, it appears that SPC may be considered a potential raw material for seed recovery. Moreover, dried strawberry press cake, and especially its seedless fraction (ESF), despite substantial contamination with sand, may be used as rich and widely available raw material for the extraction of proanthocyanidins and/or ellagitannins, and especially dimeric agrimoniin.
\end{abstract}

M. Sójka $(\bowtie) \cdot$ E. Klimczak · J. Macierzyński · K. Kołodziejczyk Faculty of Biotechnology and Food Science, Institute of Chemical Technology of Food, Lodz University of Technology, Stefanowskiego 4/10, 90-924 Lodz, Poland e-mail: michal.sojka@p.lodz.pl
Keywords By-products · Flesh · Flavanols . Ellagitannins · Agrimoniin

\section{Introduction}

Strawberry (Fragaria $\times$ ananassa Duch.) is one of the most important fruits, which adapts to various environmental growth conditions [1]. Strawberry fruits are not only attractive for their delicious taste and fresh aroma, but also for their nutritional values and antioxidant properties [2]. Their commercial production for the fresh fruit market and the processing industry has increased significantly in recent years, and in 2010, the world's strawberry production was 4.4 million tons [3]. The future of strawberry production and sales is very promising. Poland, with its output of 176,000 tons, is a leading producer of strawberries in Europe [3]. Strawberries occupy an important position in the Polish frozen fruit industry and in industrial manufacturing of strawberry concentrates [4].

According to many studies, high consumption of fruits and vegetables decreases the risk of developing many diseases of civilization. This is partially linked to the presence of health-promoting substances in plant products [5, 6]. Their beneficial influence is exerted by means of various complementary mechanisms that involve a number of bioactive compounds such as tannins, flavonoids, and phenolic acids [7]. Strawberries are known to be a rich source of polyphenols, such as ellagitannins (ETs) [8, 9], proanthocyanidins $[4,10,11]$, anthocyanins $[4,12]$, and flavonols (mostly quercetin and kaempferol glycosides) $[2,13]$. Ellagitannins are thought to be the most important polyphenols in strawberries. They are high molecular weight esters of monosaccharides, usually $\beta$-D-glucose and several hexahydroxydiphenic acid (HHDP) residues. 
According to many researchers, the main ellagitannin identified in strawberry fruits is sanguiin $\mathrm{H}-6$; however, the research of Vrhovsek et al. [14] proved at the base of NMR spectroscopy that agrimoniin, not sanguiin H-6 is the compound. The error resulted from the same mass spectrum of two compounds and the lack of standards of known, documented structure. Agrimoniin is ellagitannin present in other plant parts as well, i.e., in leafs [15] and flowers [16].

The qualitative and quantitative composition of ETs in strawberries has not been thoroughly resolved to date [7, 17]. Ellagitannins and their metabolites possess a number of health-promoting qualities, including antiviral, antibacterial, antioxidant, antimutagenic, and anticarcinogenic properties $[18,19]$. The health-promoting activity of polyphenol compounds was previously thought to be due to their strong antioxidant properties. However, nowadays, many data suggest that polyphenols play an important role as signaling molecules involved in the modulation of signal pathways, thereby affecting cellular function and gene expression, in addition to their direct effects on the digestive system [17, 20, 21].

Industrial fruit processing is accompanied by large quantities of by-products, which, if recycled, may provide an important source of substances that constitute value added in many products [22]. Industrial strawberry press cake that remains after juice processing amounts to about $4 \%$ of the weight of the raw material [23]. Fruit press cake constitutes a valuable source of health-promoting substances, and especially dietary fiber and polyphenols [2, 24, 25].

To date, studies have been conducted to determine polyphenolic content and composition of strawberry flesh and seeds, frequently named achenes, seedless strawberry purees [23, 26], as well as seeds recovered from press cake [27]. However, there are no data concerning polyphenolic content in industrial strawberry press cake, which is a waste product in the manufacture of strawberry juice. Thus, this paper presents a study on the nutrient and polyphenolic composition of industrial strawberry press cake and its seedless fraction.

\section{Materials and methods}

Plant material

The material for the research was fresh industrial strawberry press cake from modern fruit transformation plant in Masovia regions in Poland. Press cake was obtained from typical concentrated strawberry juice production, with the use of fruit mixture of 'Sega Sengana,' 'Polka,' 'Honeoye,' 'Kama,' and 'Dukat' cultivars. The cultivars are common at industrial cropping in Poland.
The materials used came from three consecutive harvest seasons 2010, 2011, and 2012. Fresh press cakes were collected from production line and dried in KC-100/200 convection dryer $1.6 \mathrm{~kW}$ (WAMiE, Warsaw, Poland), at temperature $65-70{ }^{\circ} \mathrm{C}$, for $8 \mathrm{~h}$. Dried strawberry press cakes (SPCs) were composed of seeds and seedless (flesh) fraction. All SPCs came from one production plant. Part of the fresh press cake from 2011 and 2012 harvest seasons was freeze-dried at TG 5 (VEB Hochvakuum Dresden, Germany) freeze drier and were used for determination of seedless fraction. For this purpose, freeze-dried press cake was sieved on $0.8-\mathrm{mm}$ screen. Large seeds were retained on screen, where flesh and small seeds passed through the screen. Flesh and small seeds were next sieved on $0.6-\mathrm{mm}$ screen to result the sifting deprived of seeds. Seedless part as a result of industrial strawberry pulp pressing and water extraction in press was fairly deprived of water-soluble substances, that is why that part was described as exhausted strawberry flesh (ESF). In SPC from 2010, 2011, and 2012 harvest seasons, and in EFS from 2011 and 2012 harvest seasons, the nutrients were determined, energy value was marked, and the contents of four basic polyphenol groups, i.e., ellagitannins, flavanols, anthocyanins, and flavanols were determined. Chemical composition of two additional ESF samples from 2012 harvest season was examined, first from other production day sample (2012-A), second from other production plant from Lublin region in Poland sample (2012-B). Mean laboratory samples of dried industrial press cake (SPC) and separated seedless part (ESF) were ground with liquid nitrogen in IKA A11 (IKA-Analytical Mill, Staufen, Germany) laboratory mill and allocated to below analyses.

\section{Methods}

\section{Protein determination}

Four replications of measurements of protein content in samples were made according to AOAC official method 920.152, by Kjeldahl method [28]. The results are given as \% of protein per dry matter (DM) of press cake.

\section{Fat}

Fat was determined using Soxhlet method with petroleum ether according to AOAC official method 930.09 [29]. All the samples were analyzed in duplicates. The results are expressed as \% of fat per DM of press cake.

\section{Ash (total and acid-insoluble)}

Total ash was determined according to AOAC official method 940.26 [30]. Acid-insoluble ash was determined 
according to AOAC official method 941.12 [31]. All the samples were analyzed four times. The results are expressed as \% of ash or acid-insoluble ash per DM of press cake.

\section{Total dietary fiber}

Total dietary fiber (TDF) was determined by the enzymatic weight method according to AOAC official method 985.29 [32]. The results are expressed as \% per DM of press cake.

\section{Soluble solids}

Determination of soluble solids (SS) of the materials was made according to ISO 2173:2003 method [33] using PR-32a Digital Refractometer (Atago, Tokyo, Japan). Two replicates of measurements were done for each sample, and the results are given in percentages (\%).

\section{Sugars}

Sugars glucose and fructose were determined by the HPLC method described in previous work [34].

\section{Determination of ellagitannins, flavonols, and anthocyanins}

Extraction of polyphenols was carried as previously described [35], by three steps, by the use of $70 \%$ acetone solution. $500 \mathrm{mg}$ of the ground material was placed in a 7-ml test tube, $4 \mathrm{ml}$ of a solvent was poured on it, and then, it was mixed using a vortex and sonified for $15 \mathrm{~min}$. Following the sonification, the solution was centrifuged $(4,800 \mathrm{~g})$ and poured into a flask. Above procedure was repeated twice, and the extracts were combined. The acetone was distilled from the extracts, by the use of vacuum rotary evaporator, and dry residue was dissolved in $2 \mathrm{ml}$ of $70 \%$ glycerol. Ellagitannins in glycerol solutions were submitted to acid hydrolysis as follows: $150 \mu \mathrm{l}$ of $2 \mathrm{M}$ trifluoracetic acid (Sigma-Aldrich, St. Louis, MO, USA) was added to $1 \mathrm{ml}$ of extract. The hydrolysis was carried at temperature $95 \pm 1{ }^{\circ} \mathrm{C}$, for $6 \mathrm{~h}$. The solutions before and after hydrolysis were diluted with methanol, next chromatographic analysis was carried.

The contents of free ellagic acid, agrimoniin, and other polyphenols (anthocyanins and flavonols) were determined in glycerol solutions before the hydrolysis. $0.5 \mathrm{ml}$ of above solution was diluted in $5 \mathrm{ml}$ of methanol and subjected to HPLC analysis. The content of total ellagic acid was determined after acid hydrolysis by the use of HPLC methods with the same conditions as for free ellagic acid. Sum of ellagitannins calculated as galoyl-bis-HHDP-glucose monomer was accounted by multiplication of difference between total and free ellagic acid by 1.55 factor. The factor comes from the share of ellagic acid in monomer molecule.

For the chromatographic analysis, Smartline (Knauer, Berlin, Germany) chromatograph equipped with degaser unit, two pumps, mixing chamber, autosampler, column oven, and PDA detector was used. The separation was carried on Phenomenex Gemini 5u C18 110A $(250 \times 4.60 \mathrm{~mm} ; 5 \mu \mathrm{m})$ column. The column was kept at $35{ }^{\circ} \mathrm{C}$. Eluent $\mathrm{A}$ contains $0.05 \%$ phosphoric acid in water, and eluent $\mathrm{B}$ contains $0.05 \%$ phosphoric acid in acetonitrile. Flow rate was $1.25 \mathrm{ml} / \mathrm{min}$. Gradient program was as follows: $0-5 \min 4 \% \mathrm{~B}$; $5-12.5 \min 4-15 \% \mathrm{~B}$; $12.5-42.5 \min 15-40 \% \mathrm{~B} ; 42.5-51.8 \min 40-50 \% \mathrm{~B}$; $51.8-53.4 \min 50-55 \% \mathrm{~B}$; and $53.4-55 \min 4 \% \mathrm{~B}$. The volume of injected sample was $20 \mu$ l. Detection conditions were as follows: $280 \mathrm{~nm}$ ( $p$-coumaric acid, kaempferol3- $O$ - $\beta$-D- $(6$ "-E- $p$-coumaroyl)-glucopyranoside, agrimoniin), $360 \mathrm{~nm}$ (ellagic acid, quercetin and kaempferol glycosides,quercetin, kaempferol), $520 \mathrm{~nm}$ (anthocyanins). Data were registered by ClarityChrom (Knauer, Berlin, Germany) chromatography software.

Standard curves made from ellagic acid, quercetin-3-O-glucoside, kaempferol-3-O-glucoside, quercetin, kaempferol, pelargonidin-3-O-glucoside, kaempferol3-O- $\beta$-D-(6"-E-p-coumaroyl)-glucopyranoside $\quad$ (KpCG) (Extrasynthese, Genay, France), $p$-coumaric acid (SigmaAldrich, Steinheim, Germany), and agrimoniin were used. The content of quercetin derivatives was determined as a sum of quercetin glycosides and quercetin aglycon, where the glycosides were calculated as quercetin-3-glucoside. Kaempferol derivatives were determined as a sum of glycosides and kaempferol, where glycosides were calculated as kaempferol-3-glucoside. Separately, the content of KpCG was calculated, at the base of external standard. Anthocyanins were calculated as pelargonidin-3-glucoside. Agrimoniin standard was extracted from strawberry press cake and purified by preparative chromatography.

\section{Extraction and purification of agrimoniin}

The extraction of agrimoniin was carried from ESF with $70 \%$ acetone. For this end, $100 \mathrm{~g}$ of ESF was treated by the solvent at 1:14 weight ratio and then left for maceration for $24 \mathrm{~h}$. The solution was filtered and concentrated under reduced pressure to evaporate the solvent. After that, the solution was loaded onto an AmberliteXAD-1600 N column $(8 \mathrm{~cm} \times 2 \mathrm{~cm})$. The column was rinsed with $25 \mathrm{ml}$ distilled water and eluted with $50 \mathrm{ml} 60 \% \mathrm{EtOH}$. Purified $10 \mathrm{ml}$ volume fractions were collected in tightly stopped glass flask (collector). Isolation of agrimoniin was carried by the use of Knauer (Berlin, Germany) chromatograph, composed of two pumps (Knauer K-501) forming gradient, 
Phenomenex Luna 10u C18 100A $(250 \times 21,20 \mathrm{~mm}$; $10 \mu \mathrm{m})$ (Torrance, CA, USA) column, UV-Vis detector, Foxy R1 Teledyne ISCO (Lincoln, USA) fraction collector, and Eurochrom chromatographic software. The isolation was carried from the first fraction, which was the richest in agrimoniin. Two eluents were used for separation: eluent $\mathrm{A}-0.1 \%$ formic acid in water, eluent $\mathrm{B}-80 \%$ methanol. The flow rate is $15 \mathrm{ml} / \mathrm{min}$. The following gradient was used: $0-3 \min 20 \% \mathrm{~B} ; 3-20 \min 20-35 \% \mathrm{~B} ; 20-45 \min$ $35-70 \% \mathrm{~B} ; 45-50 \min 70 \% \mathrm{~B} ; 50-55 \min 70-20 \% \mathrm{~B}$; and $55-60 \mathrm{~min} 20 \% \mathrm{~B}$. The volume of injected sample was $500 \mu$ l. Detection parameter is $280 \mathrm{~nm}$. Agrimoniin peak was collected from 10 separations, next joined, methanol was removed by distillation, and the preparation was freeze-dried. Molecular mass of agrimoniin was confirmed by ESI-MS/MS detector. Water solution of the substance was directly injected into MS detector (LCQ DECA, Thermo-Finnigan). Analyses were carried out in the positive ion mode. The source parameters were as follows: ion spray voltage, $3.00 \mathrm{kV}$; capillary temperature, $325{ }^{\circ} \mathrm{C}$; and sheath gas and auxiliary gas, 30 and 10 units/min, respectively. To generate MS/MS data, the precursor ions were fragmented by helium gas collision in the ion trap by optimizing the collision energy in order to obtain an intensity of the precursor ion close to $10 \%$ of the relative scale of the spectrum. The main pseudomolecular ion $[\mathrm{M}-\mathrm{H}]$ was observed at $1,869(\mathrm{~m} / \mathrm{z})$, and the analysis of decomposition showed the presence of 1,567, 1,265, 935, 633, and 301 $(\mathrm{m} / \mathrm{z})$ fragment ions.

\section{NMR analysis of agrimoniin}

${ }^{1} \mathrm{H}$ NMR spectrum of agrimoniin was recorded in $0.55 \mathrm{ml}$ hexadeuterated acetone $\left(99.9 \% \mathrm{CD}_{3} \mathrm{COCD}_{3}\right.$, Merck, Germany) at $25{ }^{\circ} \mathrm{C}$ on a Bruker Avance III HD 500 NMR spectrometer, equipped with 5-mm multinuclear inverse BBI probe with $z$-gradient, operating at $500.18 \mathrm{MHz}\left({ }^{1} \mathrm{H} 90^{\circ}\right.$ pulse width $=8.0 \mu \mathrm{s}$ ). Proton spectrum was referenced internally to the residual signal of protonated acetone $\delta_{\mathrm{H}}$ $2.05 \mathrm{ppm}$. The comparison of NMR spectra of main ellagitannin isolated from strawberry press cake and agrimoniin characterized by Vrhovsek et al. [14] is presented in Table 1. The ${ }^{1} \mathrm{H}$ NMR assignments for both substances are identical, which confirm agrimoniin to be the main strawberry ellagitannin. The zoom of NMR spectrum of agrimoniin (at the same range as presented by Vrhovsek et al. [14]) is shown on Fig. 1.

\section{HPLC analysis of flavanols (a sum of proantocyanidins and catechins)}

Acid-catalyzed degradation of polymeric proanthocyanidins in the excess of phloroglucinol was used for flavanols determination. The phloroglucinolysis reaction was performed according to the procedure described by Kennedy and Jones [36] with some modifications. Portion of twenty milligrams of dry powdered press cake was precisely weighed into 2-ml test tube (Eppendorf) and $800 \mu 1$ solution of phloroglucinol $(75 \mathrm{~g} / \mathrm{l})$, and ascorbic acid $(15 \mathrm{~g} / \mathrm{l})$ in dry methanol were added. The reactions were started by adding $400 \mu 1$ of $0.4 \mathrm{M} \mathrm{HCl}$ in dry methanol, and the phloroglucinolysis was carried out at $50{ }^{\circ} \mathrm{C}$ during $30 \mathrm{~min}$. The samples were next immediately cooled in an ice bath; the reaction was terminated by addition of $600 \mu l$ of water solution of sodium acetate $40 \mathrm{mM}$. Samples were stored at $4{ }^{\circ} \mathrm{C}$ before reverse phase HPLC (RP-HPLC) analysis. To determinate free catechins, the sample $0.5 \mathrm{~g}$ of press cake was subjected to triple extraction: $3 \times 3 \mathrm{ml}$ of $70 \%$ methanol, 15 min sonification. Next free catechin extracts were joined and subjected to HPLC analysis. The products of acid degradation of polymeric proanthocyanidins and free catechins were separated by the use of Knauer Smartline chromatograph (Berlin, Germany) equipped with UV-Vis detector (PDA 280, Knauer, Berlin Germany), and fluorescent detector (FD; Shimadzu RF-10Axl, Kyoto, Japan). The compounds were separated on a $250 \mathrm{~mm} \times 4.6 \mathrm{~mm}$ i.d., $5 \mu \mathrm{m}$ Gemini 5u C18 110A column (Phenomenex, Torrance, CA, USA) using gradient elution with $2.5 \%$ $(\mathrm{v} / \mathrm{v})$ acetic acid in water (A) and $80 \%(\mathrm{v} / \mathrm{v})$ acetonitrile in water (B). The column temperature was set to $25^{\circ} \mathrm{C}$. The flow rate was $1 \mathrm{ml} / \mathrm{min}$ and the gradient program was as follows: $0-10 \mathrm{~min}, 4-7 \% \mathrm{~B} ; 10-27 \mathrm{~min}, 7-30 \% \mathrm{~B}$; 27-29 min, 30-70\% B; 29-34 min, 70 \% B; 34-35 min, $70-4 \% \mathrm{~B} ; 35-40 \mathrm{~min}, 4 \% \mathrm{~B}$. The injection volume was $20 \mu \mathrm{l}$. The data were collected by the Knauer Eurochrom 2000 software. The compounds were identified by comparison of the retention times and UV-Vis spectra of standards: (-)-epicatechin, (+)-catechin, (-)-epicatechin-phloroglucinol adduct, and (+)-catechin-phloroglucinol adduct. The average degree of polymerization was measured by calculating the molar ratio of all the flavan-3-ol units (phloroglucinol adducts + terminal units) to (-)-epicatechin and $(+)$-catechin which correspond to terminal units. Quantification was carried by peak areas registered by FD at excitation wavelength $278 \mathrm{~nm}$ and emission wavelength $360 \mathrm{~nm}$. Quantities were calculated by standard curves of (-)-epicatechin and (+)-catechin for terminal units, and (-)-epicatechin-phloroglucinol adduct for extender units.

\section{Statistics}

All the results were statistically analyzed by one-way analysis of variance and post hoc Duncan test with statistical significance $p \leq 0.05$. To illustrate the difference in researched components contents between SPC and ESF, the cluster analysis was carried by k-means clustering method. 
Table 1 NMR $(500 \mathrm{MHz}$, $25^{\circ} \mathrm{C}$ ) assignments for agrimoniin in $\mathrm{CD}_{3} \mathrm{COCD}_{3}$

\begin{tabular}{|c|c|c|}
\hline Moiety & Carbon no. & ${ }^{1} \mathrm{H}$ NMR $\delta_{\mathrm{H}}$ \\
\hline \multirow[t]{7}{*}{$\alpha$-Glucose 1} & 1 & $6.55, d(4.1)$ \\
\hline & 2 & $5.34, d d(4.1,9.3)$ \\
\hline & 3 & $5.48, d d(9.6,10.2)$ \\
\hline & 4 & $5.15, t(9.5)$ \\
\hline & 5 & $4.49, d d(10.3,6.2)$ \\
\hline & 6 & $3.68, d d(13.2,0.7)$ \\
\hline & & $5.22, d d(11.8,5.2)$ \\
\hline \multirow[t]{7}{*}{$\alpha$-Glucose 2} & $1^{\prime}$ & $6.53, d(4.0)$ \\
\hline & $2^{\prime}$ & $5.36, d d(4.0,9.3)$ \\
\hline & $3^{\prime}$ & $5.54, d d(9.7,10.0)$ \\
\hline & $4^{\prime}$ & $5.19, t(8.0)$ \\
\hline & $5^{\prime}$ & $4.64, d d(10.1,6.2)$ \\
\hline & $6^{\prime}$ & $3.78, d d(13.3,0.8)$ \\
\hline & & $5.31, d d(13.3,6.6)$ \\
\hline 2- $O, 3,4,5$,-trihydroxybenzoate on $\mathrm{O}-\mathrm{C}(1)$ of glucose 1 & 6 & $7.29, s$ \\
\hline \multirow[t]{2}{*}{ 3-O,4,5-dihydroxybenzoate on $\mathrm{O}-\mathrm{C}\left(1^{\prime \prime}\right)$ of glucose 2} & 2 & $7.38, d(2.0)$ \\
\hline & 6 & $6.93, d(2.0)$ \\
\hline \multirow[t]{2}{*}{ 2,3 HHDP on glucose 1} & 2 & $6.43, s$ \\
\hline & 11 & $6.33, s$ \\
\hline \multirow[t]{2}{*}{ 4,6 HHDP on glucose 1} & 2 & $6.60, s$ \\
\hline & 11 & $6.65, s$ \\
\hline \multirow[t]{2}{*}{$2^{\prime}, 3^{\prime \prime} \mathrm{HHDP}$ on glucose 2} & 2 & $6.55, s$ \\
\hline & 11 & $6.34, s$ \\
\hline \multirow[t]{2}{*}{$4^{\prime}, 6^{\prime}$ HHDP on glucose $2^{\prime}$} & 2 & $6.59, s$ \\
\hline & 11 & $6.64, s$ \\
\hline
\end{tabular}

Statistic analysis was carried by Statistica version 7 software (StatSoft, Tulsa, USA).

\section{Results and discussion}

Nutrient and polyphenolic composition of strawberry press cake (SPC)

The basic chemical composition of industrial strawberry press cakes obtained from one processing facility over three consecutive harvest seasons is given in Table 2 .

The dry matter of strawberry press cake (SPC) contained $17 \%$ protein and $10 \%$ fat on average. No statistically significant differences in protein and fat levels were found in SPC from different seasons. Total ash content in the dry matter of SPC amounted to 4.0-7.6\%, while acidinsoluble ash content ranged from 1.8 to $5.7 \%$. These considerable differences in total ash content result from the various degrees of press cake contamination with sand in different seasons. Practice shows that acid-insoluble ash content rises significantly if the fruits are collected immediately following heavy rainfall. Among the tested samples, the press cake from the 2012 season was characterized by the highest ash levels, of which $\mathrm{HCl}$-insoluble ash (silica) constituted as much as $75 \%$. The mean total ash content less $\mathrm{HCl}$-insoluble ash content in dried SPC was $2.3 \%$, which was almost two times lower than total ash content in the dry matter of the fruits, which was $4.4 \%$ [2]. This is largely due to removal of potassium salts with juice during pressing the pulp. The mean content of TDF in the dry matter of SPC from three seasons was $60 \%$. For comparison, strawberries contain from 16 to $22 \%$ TDF in their dry matter $[2,37]$. Therefore, strawberry press cake may be considered a source of TDF which is three times as rich as the fruits themselves [2]. Carbohydrates constitute from 5.3 to $10.2 \%$ of the press cake by weight. This wide range may be due to the juice production conditions, including the dose and type of enzyme and the intensity of pulp pressing and extraction, which usually depend on the price and availability of the raw material. The average energy value of $100 \mathrm{~g}$ of dried industrial strawberry press cake calculated on the basis of the content of proteins, fats, dietary fiber, and carbohydrates in accordance with the Commission Directive 2008/100/EC amounts to $309 \mathrm{kcal} / 100 \mathrm{~g}$ and is almost 10 times higher than the energy value of strawberry 


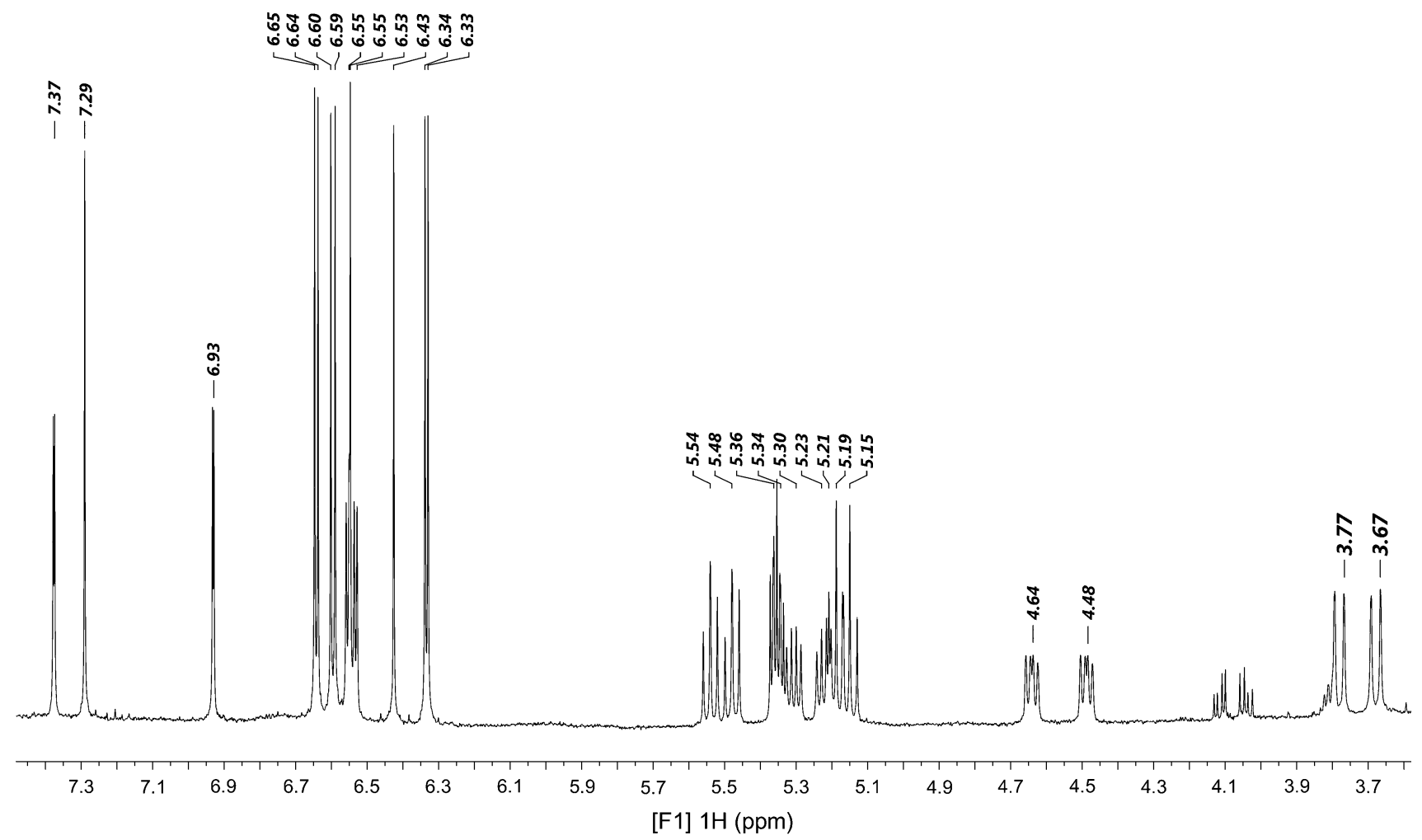

Fig. $1{ }^{1} \mathrm{H}$ NMR spectrum in acetone- $d 6$ of agrimoniin

fruits $(32 \mathrm{kcal} / 100 \mathrm{~g})[2,38]$. This results from the fact that water is removed from press cake, as opposed to proteins and fats. The latter, being high-energy compounds, largely compensate for the energy value lost with the sugars removed with juice. The content of soluble solids (SS) and sugars in press cake are useful criteria for the distribution of fruit components between the juice and press cake as well as for the efficiency of juice production from the raw material. The data in Table 2 show that strawberry press cake contains $9.2-19.7 \%$ SS and from 0.7 to $7.0 \%$ glucose and fructose combined. The content of SS, as well as glucose and fructose, in press cake from 2011 is significantly different from that from the other two seasons. Therefore, the press cake from 2011 has a much higher energy value. For comparison, strawberry fruits contain about $20 \%$ glucose and $24.4 \%$ fructose per unit of dry matter [2]. The composition of nutrients in industrial press cake may be said to be repeatable. This is probably due to using the same raw material base, the same processing conditions, and the low variation of strawberry fruits in terms of nutrients. Despite the fact that strawberry press cake is characterized by high levels of TDF, proteins, and fats, its considerable and uneven contamination with silica (sand) creates substantial risk if it is used for consumption purposes.

The polyphenolic composition of SPC from the 2010, 2011, and 2012 seasons is shown in Table 2; chromatograms of determined components are presented on Fig. 2. Despite many studies on strawberries, knowledge concerning the polyphenolic composition of its industrial by-products is still unsatisfactory. There are no literature data concerning total polyphenols in industrial press cake. There are only a few studies on the polyphenolic composition of seeds and waste by-products of seedless strawberry puree production [23]. In turn, Oszmiański et al. [10], who studied the industrial production of concentrated strawberry juice, focused only on variations in the raw material and polyphenols in juice at various stages of the process. The main polyphenol groups in SPC are flavanols (proanthocyanidins and catechins), which constitute $56 \%$ of total polyphenols, and ellagitannins, which constitute nearly $40 \%$ of polyphenols in press cake. Thus, tannins, both condensed and hydrolyzable, account for $96 \%$ of total polyphenols in the press cake. Flavonols, that is, quercetin and kaempferol glycosides, are the next most abundant group of polyphenols, accounting for almost $4 \%$ of total polyphenols.

The content of flavanols in the studied SPC material is in the range of $1,103-2,666 \mathrm{mg} / 100 \mathrm{~g}$ DW. Their levels vary significantly in the press cakes from the three studied seasons. The high content of flavanols (mostly proanthocyanidins) in the press cake is linked to the fact that they bind strongly to cell walls [39], due to which their presence 
Table 2 Content of basic nutrient components $(\mathrm{g} / 100 \mathrm{~g}$ sample DW), energy value (kcal/100 g sample DW), phenolic compounds (mg/100 g sample DW), molar proportion of constituent flavanols, and mean DP of proanthocyanidins in industrial SPC
Values are expressed as mean \pm standard deviation (SD)

Caloric value was calculated according to Commission Directive 2008/100/EC

The results in the individual rows marked by the same letter are not statistically different at $p<0.05$

$n$ number of measurements, $T D F$ total dietary fiber, $M C$ metabolized carbohydrates, $S S$ total soluble solids, $E V$ energy value; Total ET total ellagitannins, $K p C G$ Kaempferol-3- $O$ - $\beta$-D- $\left(6^{\prime \prime}-\mathrm{E}-p\right.$ coumaroyl)-glucopyranoside, $m D P$ mean degree of polymerization, $T P H$ total polyphenols

\begin{tabular}{|c|c|c|c|c|}
\hline Component & SPC 2010 & SPC 2011 & SPC 2012 & Mean \\
\hline Protein $(n=4)$ & $17.6 \pm 0.5 \mathrm{a}$ & $16.8 \pm 0.6 \mathrm{a}$ & $16.7 \pm 0.2 \mathrm{a}$ & $17.3 \pm 0.6$ \\
\hline Fat $(n=2)$ & $10.2 \pm 0.1 \mathrm{a}$ & $9.5 \pm 0.6 \mathrm{a}$ & $9.6 \pm 0.1 \mathrm{a}$ & $9.8 \pm 0.5$ \\
\hline Total ash & $5.1 \pm 0.6 b$ & $4.0 \pm 0.0 \mathrm{a}$ & $7.6 \pm 2.3 b$ & $5.7 \pm 0.8$ \\
\hline $\begin{array}{l}\text { (HCl-insoluble ash) } \\
\quad(n=4)\end{array}$ & $(2.7 \pm 0.5 b)$ & $(1.8 \pm 0.1 \mathrm{a})$ & $(5.7 \pm 2.5 \mathrm{c})$ & $(3.4 \pm 0.7)$ \\
\hline $\operatorname{TDF}(n=4)$ & $61.8 \pm 1.0 \mathrm{~b}$ & $59.5 \pm 0.5 \mathrm{a}$ & $58.6 \pm 0.1 \mathrm{a}$ & $60.0 \pm 1.6$ \\
\hline $\operatorname{MC}(n=4)$ & $5.3 \pm 0.8 \mathrm{a}$ & $10.2 \pm 0.5 b$ & $9.5 \pm 0.4 b$ & $8.3 \pm 2.5$ \\
\hline $\operatorname{SS}(n=2)$ & $11.9 \pm 1.5 \mathrm{a}$ & $19.7 \pm 1.9 \mathrm{~b}$ & $9.2 \pm 1.4 \mathrm{a}$ & $13.6 \pm 5.1$ \\
\hline Glucose $(n=2)$ & $0.3 \pm 0.1 \mathrm{a}$ & $3.2 \pm 0.3 c$ & $0.8 \pm 0.0 \mathrm{~b}$ & $1.4 \pm 1.4$ \\
\hline Fructose $(n=2)$ & $0.4 \pm 0.1 \mathrm{a}$ & $3.8 \pm 0.2 \mathrm{c}$ & $1.0 \pm 0.1 b$ & $1.8 \pm 1.6$ \\
\hline $\begin{array}{l}\mathrm{EV}(\mathrm{kcal} / 100 \mathrm{~g} \mathrm{DW}) \\
(n=4)\end{array}$ & $307.2 \pm 0.3 \mathrm{a}$ & $312.6 \pm 3.1 b$ & $308.3 \pm 0.1 \mathrm{a}$ & $310 \pm 3$ \\
\hline Ratio sugars/SS (\%) & 5.9 & 35.5 & 19.6 & 18.4 \\
\hline \multicolumn{5}{|c|}{ Polyphenols (mg/100 g sample DW) $(n=2)$} \\
\hline Free ellagic acid & $105.2 \pm 5.9 \mathrm{c}$ & $83.3 \pm 0.5 b$ & $104.5 \pm 4.1 \mathrm{c}$ & $99.0 \pm 12.5$ \\
\hline Total ellagic acid & $977.6 \pm 39.4 b$ & $1,218.8 \pm 42.0 \mathrm{c}$ & $735.9 \pm 32.4 \mathrm{a}$ & $985.1 \pm 218.2$ \\
\hline Total ET & $1,381.7 \pm 56.2 b$ & $1,760.1 \pm 66.0 \mathrm{c}$ & $978.6 \pm 56.6 \mathrm{a}$ & $1,373.5 \pm 352.6$ \\
\hline Agrimoniin & $347.8 \pm 17.7 \mathrm{a}$ & $667.2 \pm 42.2 b$ & $864.2 \pm 35.0 \mathrm{c}$ & $654.6 \pm 283.1$ \\
\hline Quercetin derivatives & $18.4 \pm 1.7 \mathrm{a}$ & $37.9 \pm 0.2 \mathrm{c}$ & $34.4 \pm 3.6 b . c$ & $30.7 \pm 8.7$ \\
\hline Keampferol derivatives & $10.2 \pm 1.6 \mathrm{a}$ & $39.7 \pm 1.7 \mathrm{c}$ & $33.5 \pm 3.0 \mathrm{~b}$ & $27.1 \pm 15.0$ \\
\hline $\mathrm{KpCG}$ & $44.1 \pm 2.1 \mathrm{a}$ & $96.2 \pm 4.6 c$ & $80.1 \pm 5.6 b$ & $72.7 \pm 25.3$ \\
\hline Anthocyanins & $78.2 \pm 3.9 b$ & $92.7 \pm 2.5 b . c$ & $47.6 \pm 4.5 \mathrm{a}$ & $73.8 \pm 21.1$ \\
\hline Flavanols & $1,102.8 \pm 15.7 \mathrm{a}$ & $2,170.8 \pm 136.8 \mathrm{c}$ & $1,604.9 \pm 69.8 b$ & $1,626.2 \pm 534.3$ \\
\hline$(+)$-Catechin & $13.7 \pm 0.2 \mathrm{a}$ & $30.5 \pm 0.1 b$ & $40.0 \pm 0.9 c$ & $28.0 \pm 13.3$ \\
\hline Proanthocyanidins & $1,089.1 \pm 20.0 \mathrm{a}$ & $2,140.3 \pm 136.6 \mathrm{c}$ & $1,564.9 \pm 70.7 b$ & $1,598.1 \pm 526.4$ \\
\hline \multicolumn{5}{|l|}{ Terminal units (\%) } \\
\hline$(+)$-Catechin & $17.3 \pm 0.3 b$ & $14.3 \pm 0.8 \mathrm{a}$ & $15.9 \pm 0.5 \mathrm{ab}$ & $15.8 \pm 1.5$ \\
\hline (-)-Epicatechin & $0.9 \pm 0.1 \mathrm{a}$ & $1.0 \pm 0.1 \mathrm{a}$ & $0.7 \pm 0.1 \mathrm{a}$ & $0.9 \pm 0.2$ \\
\hline \multicolumn{5}{|l|}{ Extension units (\%) } \\
\hline$(+)$-Catechin & $20.3 \pm 0.3 b$ & $17.3 \pm 1.0 \mathrm{a}$ & $20.0 \pm 0.7 b$ & $19.2 \pm 1.7$ \\
\hline (-)-Epicatechin & $61.5 \pm 2.0 \mathrm{a}$ & $67.4 \pm 4.4 \mathrm{a}$ & $63.3 \pm 3.3 \mathrm{a}$ & $64.1 \pm 3.0$ \\
\hline $\mathrm{mDP}$ & $5.8 \pm 0.2 \mathrm{a}$ & $7.1 \pm 0.0 \mathrm{~b}$ & $6.9 \pm 0.1 b$ & $6.6 \pm 0.7$ \\
\hline TPH & $2,582.5 \pm 59.0 \mathrm{a}$ & $3,871.1 \pm 404.5 b$ & $3,840.4 \pm 203.7 b$ & $3,449.0 \pm 664.0$ \\
\hline
\end{tabular}

in the juices produced is very limited. This is further confirmed by other results reported by Oszmiański et al. [10], who found that in a typical process of concentrated strawberry juice production, about $20 \%$ of the proanthocyanidins present in the fruits are transferred to the juice (the content of proanthocyanidins in the raw material was not less than $1,417 \mathrm{mg}$ per $\mathrm{kg}$ fresh weight). According to Buendia et al. [11], the levels of proanthocyanidins in the fruits of various cultivars of strawberries, determined by HPLC following the phloroglucinolysis reaction, range from 539 to $1,681 \mathrm{mg} / 100 \mathrm{~g} \mathrm{DW}$ (given $10 \%$ mean dry matter content of the fruits). Their results confirm that proanthocyanidins are strongly bound in the press cake, despite the intensive processing procedures involving enzymatic treatment, pressing, and extraction. Mean degree of polymerization of SPC proanthocyanidins was 6.7 , the value is slightly higher than data by Buendia et al. [11] for fruits, where mean DP depended on cultivar and varied between 3.4 and 5.8. In researched SPC, polymeric flavanols were composed of (+)-catechin and (-)-epicatechin which are constitutive units of procyanidins (Fig 3.). According to Buendia et al. [11] and Gu et al. [40], epiafzelchin (the unit of propelargonidin) composes strawberry proanthocyanidins as well, and its contribution as extension unit varies between 6.1 and $10.5 \%$, depending on cultivar.

Hydrolysis of ellagitannins in an acidic or basic environment leads to release of hexahydroxydiphenic acid molecules, which undergo spontaneous lactonization to ellagic acid. In the literature, the content of total ellagitannins is usually determined on the basis of the amount of ellagic acid released from their molecules [41]. Hakkinen et al. [42] indicated that ellagic acid is the main 


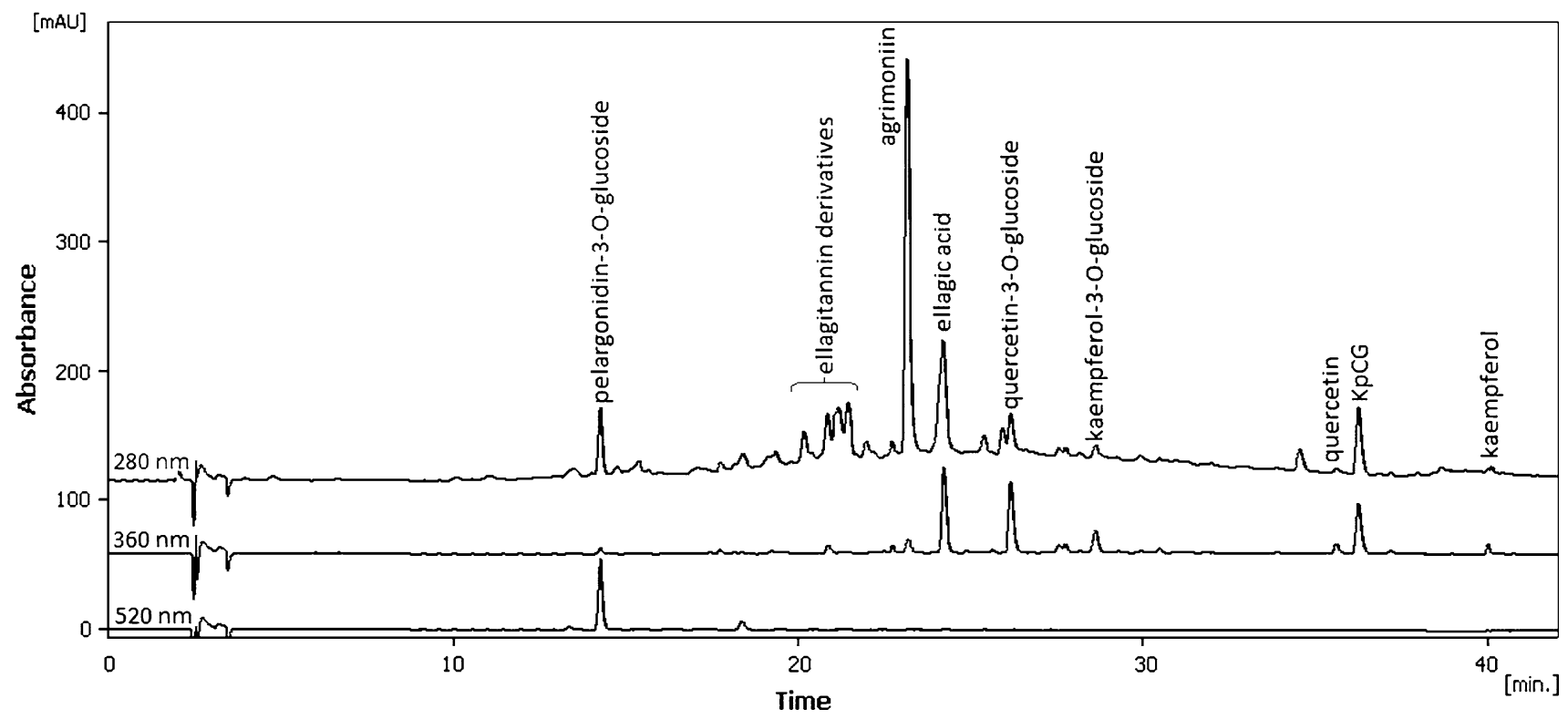

Fig. 2 HPLC chromatogram $(280 \mathrm{~nm}, 360 \mathrm{~nm}, 520 \mathrm{~nm})$ of polyphenolic compounds in SPC

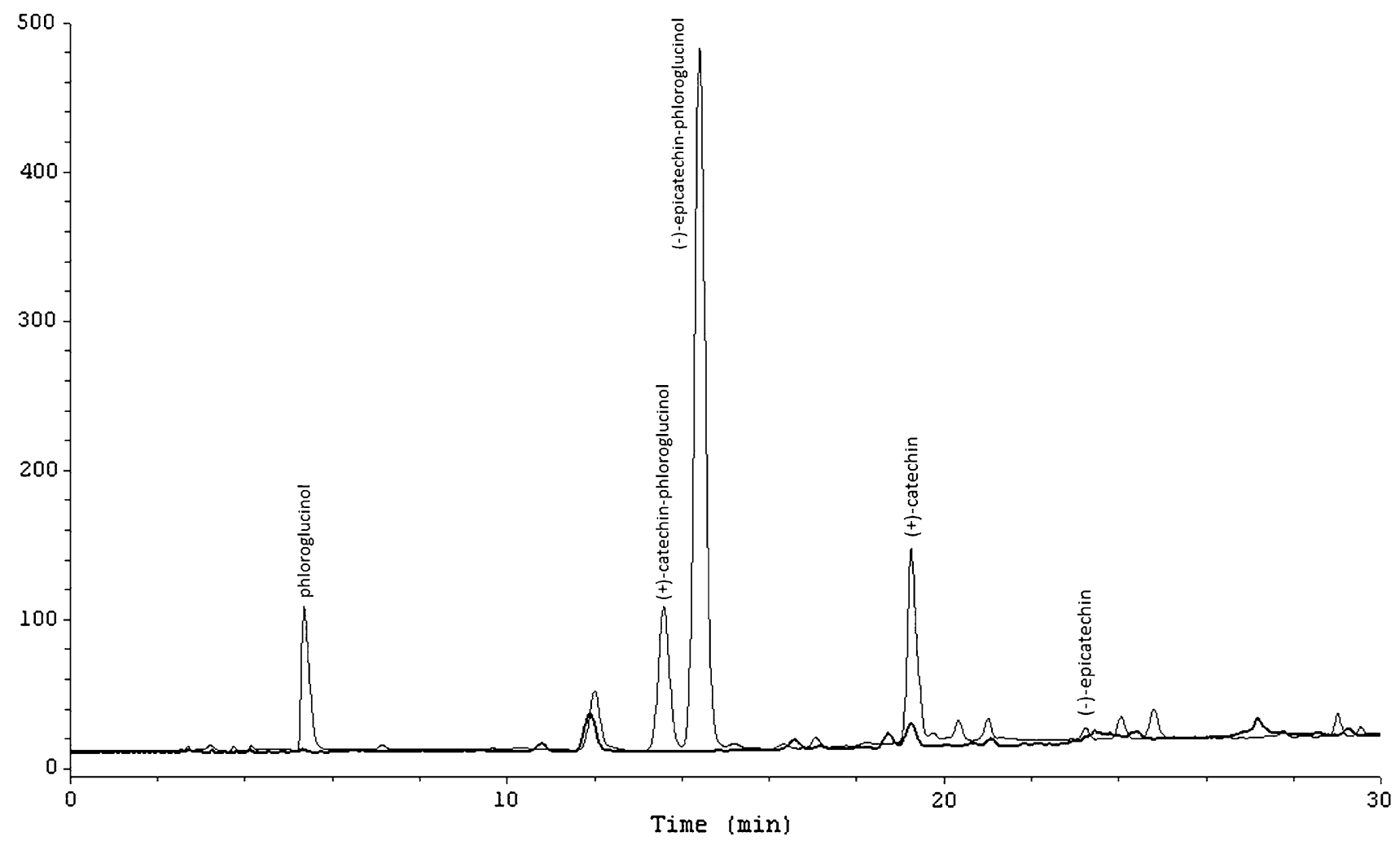

Fig. 3 Fine line-HPLC-FD chromatogram of proanthocyanidins cleavage products from SPC. Bold line-HPLC-FD chromatogram before phloroglucinolysis of proanthocyanidins from SPC

phenolic compound in the berries of the family Rosaceae, genus Fragaria, accounting for $51 \%$ of the compounds analyzed. According to Seeram et al. [7], dimer of
galloyl-bis-HHDP-glucose is the main ellagitannin of strawberry fruits and is accompanied by galloyl-bis-HHDPglucose and isomers of galloyl-HHDP-glucose. The total 
content of ellagitannins in strawberries is estimated to be $65-85 \mathrm{mg} / 100 \mathrm{~g} \mathrm{FW}$ (fresh weight), which corresponds to approximately $650-850 \mathrm{mg} / 100 \mathrm{~g} \mathrm{DW}$ [43]. It should be remembered, that ETs are usually determined in fresh fruits or in fruits dried by sublimation, that is, in materials not exposed to elevated temperature [7]. Okuda et al. [44] reported that ellagitannins may lose HHDP residues, leading to the formation of new substances. Thus, in the studied press cake, along with total ellagic acid (which may be linked to monomeric and dimeric ellagitannins), agrimoniin levels were determined separately.

The content of agrimoniin-dried strawberry press cake ranges from 348 to $864 \mathrm{mg} / 100 \mathrm{~g}$ DW. The low content of agrimoniin in SPC from the 2010 season is accompanied by a relatively high content of $p$-coumaric acid $(20.6 \mathrm{mg} / 100 \mathrm{~g}$ DW), which probably means that the studied press cakes were not thoroughly extracted and may have been a byproduct of processing strawberries with hulls ( $p$-coumaric acid was not found in SPC from 2011 to 2012). All the analyzed industrial press cake samples differ significantly in terms of total ellagic acid and agrimoniin levels (Table 2). This confirms considerable variation of ET content in the raw material. This was also reported by Oszmiański et al. [10] and Willner el al. [9], who showed that the total content of ellagic acid in strawberries is differentiated by cultivar and ripening stage. According to Hakkinen et al. [42], total ellagic acid content in strawberry fruits of various cultivars ranges from 344 to $580 \mathrm{mg} / 100 \mathrm{~g} \mathrm{DW}$. In terms of galloyl-bis-HHDP-glucose (1.55 $\times$ total ellagic acid), these results correspond to 530 and $900 \mathrm{mg} / 100 \mathrm{~g} \mathrm{DW}$. The levels of free ellagic acid in dried strawberry press cake are from 83 to $105 \mathrm{mg} / 100 \mathrm{~g}$ DW. The variation in the content of free ellagic acid may result from different interactions of enzymes with the pulp, or from other processing factors [10].

Kaempferol-3-O- $\beta$ - D- (6" - E- p-coumaroy 1$)$ glucopyranoside $(\mathrm{KpCG})$ is the predominant flavonol in SPC (44-96 mg/100 g DW), and it revealed significant variation between the three studied seasons. The levels of quercetin glycosides in strawberry press cake range from 18.4 to $37.9 \mathrm{mg} / 100 \mathrm{~g}$ DW. The content of kaempferol glycosides apart from KpCG is $10.2-39.7 \mathrm{mg} / 100 \mathrm{~g} \mathrm{DW}$, while the press cake from 2010 has significantly lower levels of flavonol glycosides, including quercetin and kaempferol glycosides and KpCG, as compared to the press cakes from 2011 to 2012.

The content of anthocyanins in the press cake is as little as $0.2 \%$ of total polyphenols, while in the fruits, they account for $13-45 \%$ of total polyphenols $[4,11]$. Depending on the season, the studied press cakes contain from 47 to $87 \mathrm{mg}$ of anthocyanins per $100 \mathrm{~g}$ DW. The low levels of anthocyanins in the press cakes are due to the fact that they are located in vacuoles and are removed during highly efficient juice extraction. According to Oszmiański et al. [10], $90 \%$ of anthocyanins are transferred from the fruits to the juice during industrial production of concentrated strawberry juice.

\section{Nutrient and polyphenol composition of ESF}

Strawberry press cake (SPC) is a dehydrated by-product of pressing and water extraction of fruit pulp, which is largely deprived of cell sap and hydrophilic substances. SPC may be separated into flesh and seeds. Substantial loss of mass and soluble substance in the process of juice production occurs mostly in the flesh, and only to a small degree in the seeds. Seeds have hard and not readily permeable pericarps; for that reason, they preserve their components, and especially fats, proteins, and polysaccharides. Therefore, the seedless fraction of press cake is called exhausted strawberry flesh (ESF). Similarly to press cakes from other berries, SPC is a mixture of these two components (seeds and ESF), which differ from each other in terms of morphology, chemical composition, and use [27, 34]. In the present work, on a laboratory scale, we obtained on average $60 \% \mathrm{ESF}$ (with a particle size of $<0.6 \mathrm{~mm}$ ) from industrial SPC dried by freeze-drying. Table 3 below shows the nutrient and polyphenolic composition of the seedless fraction of industrial strawberry cake.

Material was obtained from two fruit and vegetable processing companies (designated A and B). Samples from company A were from the 2011 and 2012 seasons, and samples from company B only from the 2012 season. The analyzed ESF fractions are characterized by high TDF levels, ranging from 52 to $62 \%$ in dry weight; they also contain from 19.3 to $21.5 \%$ protein and from 3.1 to $3.5 \%$ fat. Total ash level was found to vary considerably (from 4.3 to $8.9 \mathrm{~g} / 100 \mathrm{~g} \mathrm{DW}$ ) in these fractions. All samples from 2012 contain significantly more ash as compared to 2011, which shows that this differentiating factor is dependent on harvest conditions. The high and uneven contamination of ESF fractions with sand is the main disadvantage of this material, which is harvested from soil, and limits ESF use for consumption purposes. The mean energy value of ESF is $276 \mathrm{kcal} / 100 \mathrm{~g} \mathrm{DW}$ and is slightly lower than that of SPC (309 kcal/100 g DW). The content of soluble substances as well as glucose and fructose was significantly higher in the 2011 sample. Differences in the levels of carbohydrates probably result from the varying efficiency of separating the juice from the press cake and extraction of the latter.

Table 3 shows the polyphenolic composition of the ESF fraction. The mean ESF content of ellagitannins, considered to be the most important polyphenolic components, amounts to $1,499 \mathrm{mg}$ per $100 \mathrm{~g}$ DW of the material, which corresponds to $28 \%$ of total polyphenols. ET content is significantly higher in ESF obtained from the press cake 
Table 3 Content of basic nutrient components (g/100 g DW of sample), energy value ( $\mathrm{kcal} / 100 \mathrm{~g}$ DW of sample), phenolic compounds (mg/100 g DW of sample), molar proportion of constituent flavanols, and mean DP of proanthocyanidins in ESF from the 2011 and 2012 seasons

\begin{tabular}{|c|c|c|c|c|c|}
\hline Component & $\operatorname{ESF}(2011)$ & ESF (2012) & ESF (2012-A) & ESF (2012-B) & Mean \\
\hline Protein $(n=4)$ & $19.3 \pm 0.1 \mathrm{a}$ & $21.5 \pm 1.1 \mathrm{a}$ & $19.7 \pm 0.9 \mathrm{a}$ & $21.1 \pm 0.9 \mathrm{a}$ & $20.4 \pm 1.2$ \\
\hline Fat $(n=2)$ & $3.1 \pm 0.1 \mathrm{a}$ & $3.6 \pm 0.0 \mathrm{~b}$ & $3.7 \pm 0.0 \mathrm{~b}$ & $3.7 \pm 0.0 \mathrm{~b}$ & $3.5 \pm 0.3$ \\
\hline Ash & $4.3 \pm 0.3 \mathrm{a}$ & $8.9 \pm 0.1 \mathrm{c}$ & $8.1 \pm 0.2 b$ & $8.4 \pm 0.2 b . c$ & $7.4 \pm 2.0$ \\
\hline$($ HCl-insoluble ash $)(n=4)$ & $(2.4 \pm 0.2 a)$ & $(7.2 \pm 0.0 \mathrm{~d})$ & $(6.4 \pm 0.0 b)$ & $(6.5 \pm 0.1 c)$ & $5.6 \pm 2.0$ \\
\hline $\operatorname{TDF}(n=4)$ & $52.8 \pm 0.1 \mathrm{a}$ & $55.4 \pm 0.4 b$ & $61.6 \pm 0.1 \mathrm{c}$ & $55.0 \pm 0.4 b$ & $56.2 \pm 3.5$ \\
\hline $\mathrm{MC}(n=4)$ & $20.6 \pm 0.3 c$ & $10.6 \pm 1.5 b$ & $7.0 \pm 1.0 \mathrm{a}$ & $11.8 \pm 0.4 b$ & $12.5 \pm 5.4$ \\
\hline $\operatorname{SS}(n=2)$ & $27.6 \pm 1.9 \mathrm{~b}$ & $13.1 \pm 0.0 \mathrm{a}$ & $10.5 \pm 0.2 \mathrm{a}$ & $11.7 \pm 1.8 \mathrm{a}$ & $15.7 \pm 7.5$ \\
\hline Glucose $(n=2)$ & $5.5 \pm 0.3 \mathrm{c}$ & $1.0 \pm 0.0 \mathrm{~b}$ & $0.9 \pm 0.0 \mathrm{~b}$ & $0.5 \pm 0.0 \mathrm{a}$ & $2.0 \pm 2.2$ \\
\hline Fructose $(n=2)$ & $6.6 \pm 0.4 b$ & $1.2 \pm 0.1 \mathrm{a}$ & $1.1 \pm 0.1 \mathrm{a}$ & $0.8 \pm 0.1 \mathrm{a}$ & $2.4 \pm 2.6$ \\
\hline $\mathrm{EV}(\mathrm{kcal} / 100 \mathrm{~g} \mathrm{DW})(n=4)$ & $292.8 \pm 0.6 \mathrm{~d}$ & $271.8 \pm 1.0 \mathrm{~b}$ & $263.0 \pm 0.7 \mathrm{a}$ & $274.8 \pm 1.4 \mathrm{c}$ & $276 \pm 12$ \\
\hline Ratio sugars/SS (\%) & 40.2 & 16.8 & 19.0 & 11.1 & 21.8 \\
\hline \multicolumn{6}{|c|}{ Polyphenols (mg/100 g DW) $(n=2)$} \\
\hline Free ellagic acid & $88.8 \pm 0.1 \mathrm{a}$ & $98.4 \pm 0.4 a$ & $90.6 \pm 9.6 \mathrm{a}$ & $98.9 \pm 0.2 \mathrm{a}$ & $94.2 \pm 6.0$ \\
\hline Total ellagic acid & $1,194.3 \pm 31.5 b$ & $1,051.2 \pm 10.4 \mathrm{a} . \mathrm{b}$ & $924.3 \pm 60.2 \mathrm{a}$ & $1,014.7 \pm 7.5 \mathrm{a}$ & $1,046.1 \pm 114.2$ \\
\hline Total ellagitannins & $1,713.5 \pm 48.8 b$ & $1,476.7 \pm 15.4 \mathrm{a}, \mathrm{b}$ & $1,292.2 \pm 171.5 \mathrm{a}$ & $1,419.4 \pm 11.6 \mathrm{a}$ & $1,475.5 \pm 176.9$ \\
\hline Agrimoniin & $1,012.2 \pm 11.0 \mathrm{a}$ & $933.0 \pm 3.7 \mathrm{a}$ & $937.9 \pm 86.7 \mathrm{a}$ & $973.1 \pm 36.4 \mathrm{a}$ & $964.1 \pm 49.4$ \\
\hline Quercetin derivatives & $57.0 \pm 0.3 b$ & $48.7 \pm 1.1 \mathrm{a}$ & $49.0 \pm 4.0 \mathrm{a}$ & $46.8 \pm 1.7 \mathrm{a}$ & $50.4 \pm 4.5$ \\
\hline Keampferol derivatives & $36.9 \pm 3.1 \mathrm{a}$ & $32.5 \pm 2.1 \mathrm{a}$ & $33.8 \pm 4.5 \mathrm{a}$ & $36.2 \pm 0.7 \mathrm{a}$ & $34.8 \pm 2.9$ \\
\hline $\mathrm{KpCG}$ & $16.6 \pm 1.3 \mathrm{a}$ & $17.9 \pm 0.8 \mathrm{a}$ & $23.2 \pm 1.4 b$ & $31.5 \pm 1.4 \mathrm{c}$ & $22.3 \pm 6.3$ \\
\hline Anthocyanins & $101.2 \pm 2.0 \mathrm{~b}$ & $57.7 \pm 0.3 \mathrm{a}$ & $54.0 \pm 5.6 \mathrm{a}$ & $112.4 \pm 0.7 \mathrm{c}$ & $81.3 \pm 27.7$ \\
\hline Flavanols & $3,630.5 \pm 93.1 \mathrm{a}$ & $3,739.0 \pm 205.6 \mathrm{a}$ & $3,750.7 \pm 52.1 \mathrm{a}$ & $3,862.9 \pm 259.6 a$ & $3,745.8 \pm 158.2$ \\
\hline$(+)$-Catechin & $19.7 \pm 0.1 \mathrm{a}$ & $26.2 \pm 0.2 \mathrm{~d}$ & $22.0 \pm 0.2 \mathrm{c}$ & $21.1 \pm 0.3 b$ & $22.2 \pm 2.8$ \\
\hline Proanthocyanidins & $3,610.8 \pm 93.0 \mathrm{a}$ & $3,712.9 \pm 205.8 \mathrm{a}$ & $3,728.8 \pm 52.3 \mathrm{a}$ & $3,841.8 \pm 259.3 \mathrm{a}$ & $3,723.6 \pm 94.6$ \\
\hline \multicolumn{6}{|l|}{ Terminal units (\%) } \\
\hline$(+)$-Catechin & $13.3 \pm 0.4 \mathrm{a}$ & $12.6 \pm 0.4 \mathrm{a}$ & $12.5 \pm 0.2 \mathrm{a}$ & $13.3 \pm 1.3 \mathrm{a}$ & $12.9 \pm 0.4$ \\
\hline (-)-Epicatechin & $0.9 \pm 0.0 \mathrm{a}$ & $0.8 \pm 0.1 \mathrm{a}$ & $0.8 \pm 0.0 \mathrm{a}$ & $1,5 \pm 1.0 \mathrm{a}$ & $1.0 \pm 0.3$ \\
\hline \multicolumn{6}{|l|}{ Extension units (\%) } \\
\hline$(+)$-Catechin & $15.7 \pm 0.5 \mathrm{a}$ & $16.4 \pm 0.8 \mathrm{a}$ & $16.8 \pm 0.3 \mathrm{a}$ & $15,9 \pm 0.7 \mathrm{a}$ & $16.2 \pm 0.5$ \\
\hline (-)-Epicatechin & $70.1 \pm 1.6 \mathrm{a}$ & $70.2 \pm 4.3 \mathrm{a}$ & $69.9 \pm 0.9 a$ & $69.3 \pm 3.7 \mathrm{a}$ & $69.9 \pm 0.4$ \\
\hline $\mathrm{mDP}$ & $7.3 \pm 0.1 \mathrm{a}$ & $7.8 \pm 0.2 \mathrm{a}$ & $7.8 \pm 0.0 \mathrm{a}$ & $7.0 \pm 0.7 \mathrm{a}$ & $7.5 \pm 0.4$ \\
\hline TPH & $5,555.7 \pm 148.0 \mathrm{a}$ & $5,372.6 \pm 223.8 \mathrm{a}$ & $5,202.9 \pm 239.1 \mathrm{a}$ & $5,509.3 \pm 272.3 \mathrm{a}$ & $5,410.1 \pm 224.9$ \\
\hline
\end{tabular}

Values are expressed as mean \pm standard deviation (SD)

Caloric value was calculated according to Commission Directive 2008/100/EC

The results in the individual rows marked by the same letter are not statistically different at $p<0.05$

$n$ number of measurements, $T D F$ total dietary fiber, $M C$ metabolized carbohydrates, $S S$ total soluble solids, $E V$ energy value, Total ET total ellagitannins, $K p C G$ Kaempferol-3- $O-\beta$-D-(6"-E-p-coumaroyl)-glucopyranoside, $m D P$ mean degree of polymerization, $T P H$ total polyphenols

from 2011. The mean amount of free ellagic acid in the studied material is $94 \mathrm{mg} / 100 \mathrm{~g}$ DW. According to Aaby et al. [23], free ellagic acid levels in strawberry flesh are low, at $2.0-2.3 \mathrm{mg} / 100 \mathrm{~g} \mathrm{DW}$. The high content of ellagic acid in ESF may be linked to partial hydrolysis of ellagitannins to free acid, which remains in ESF due to its low water solubility. Similarly as in the case of SPC, flavanols (proantocyanidins most of all) are also the predominant group of polyphenols in ESF. Their mean content in particular ESF samples is slightly over 3,700 mg/100 g DW, that is, $69 \%$ of total polyphenols. Thus, the combined content of ellagitannins and tannins in total ESF polyphenols amounts to $97 \%$. Degree of polymerization of proanthocyanidins in ESF was 7.4, and the value was insignificantly higher than in SPC. The contribution of individual proanthocyanidin components in ESF was close to SPC. Statistical analysis did not reveal any significant differences in the content of flavanols or agrimoniin in the ESF fraction. Aaby et al. [23], who examined the polyphenolic composition of strawberry flesh, reported that the content of 
ellagitannins (expressed as gallic acid equivalents) ranged from 7.6 to $11.2 \mathrm{mg} / 100 \mathrm{~g} \mathrm{FW}$, and the content of procyanidins (expressed as catechin equivalents) from 13.7 to $17.9 \mathrm{mg} / 100 \mathrm{FW}$ (in the dry matter of strawberry flesh, the content of these compounds was ten times higher). The low levels of ellagitannins and procyanidins in strawberry flesh may be explained by the manner of their determination and the presence of all soluble components, including sugars, in the dry matter of the fruits. The mean content of anthocyanins in ESF is $81.3 \mathrm{mg} / 100 \mathrm{~g}$, which is similar to their content in SPC. ESF flavonols account for $5.4 \%$ of total polyphenols on average. The levels of quercetin and kaempferol glycosides in ESF amount to approximately 57 and $34.8 \mathrm{mg} / 100 \mathrm{~g}$ DW, respectively. The studied ESF samples do not differ significantly in terms of kaempferol glycoside content, and in the case of quercetin glycosides, only sample A 2011 is characterized by significantly lower levels of these compounds. The mean content of KpCG in ESF amounts to $22.3 \mathrm{mg} / 100 \mathrm{~g}$ DW. Only samples from the same company from the 2011 and 2012 seasons do not differ significantly in terms of KpCG levels. No significant differences in total polyphenols were found between all the studied ESF samples.

The nutrient and polyphenolic content of strawberry press cake and its seedless fraction was analyzed statistically using k-means cluster analysis. The data used for analysis were standardized. Figure 4 shows the results of cluster analysis with two clusters. Statistical analysis confirmed the differences between SPC and ESF, that is, one cluster contained SPC, while the other ESF. The chart represents the differences between the clusters based on distances between the points representing the studied substances (distance between points along the $Y$ axis). The long distances between the points confirm considerable differentiation of the materials in respect of the substances studied. The chart clearly shows that SPC and ESF differ significantly in terms of the content of such substances as proteins, fats, agrimoniin, quercetin glycosides, KpCG, and flavanols.

\section{Conclusions}

The most pronounced differences in nutrient and polyphenolic content between SPC and ESF are illustrated in Fig. 4. The data from Tables 2 and 3 show that ESF contains approximately $20 \%$ more protein and almost three times less fat than SPC. The higher fat levels in SPC result from the fact that it consists of approximately $40 \%$ seeds, which contain fat, similarly as the seeds of other berries. Based on the analyses conducted in this work, the estimated mean fat content in pure seeds amounts to $19.3 \%$. Thus, ESF is an undesirable burden in the manufacture of oil from strawberry seeds obtained from industrial press cake. Another inconvenience linked to ESF is the fact that it is contaminated with sand (almost $6 \%$ ) and has lower levels of macroelements components (expressed as total ash minus $\mathrm{HCl}$-insoluble ash) as compared to whole press cake. On the other hand, ESF, which is a by-product in the manufacture of seed oil from press cake, is a better source
Fig. 4 Cluster analysis of strawberry press cake materials with the use of k-means clustering; cluster 1 - strawberry press cake (square SPC), cluster 2-exhausted strawberry flesh (circle ESF); $Q D$ quercetin derivatives, $K D$ kaempferol derivatives

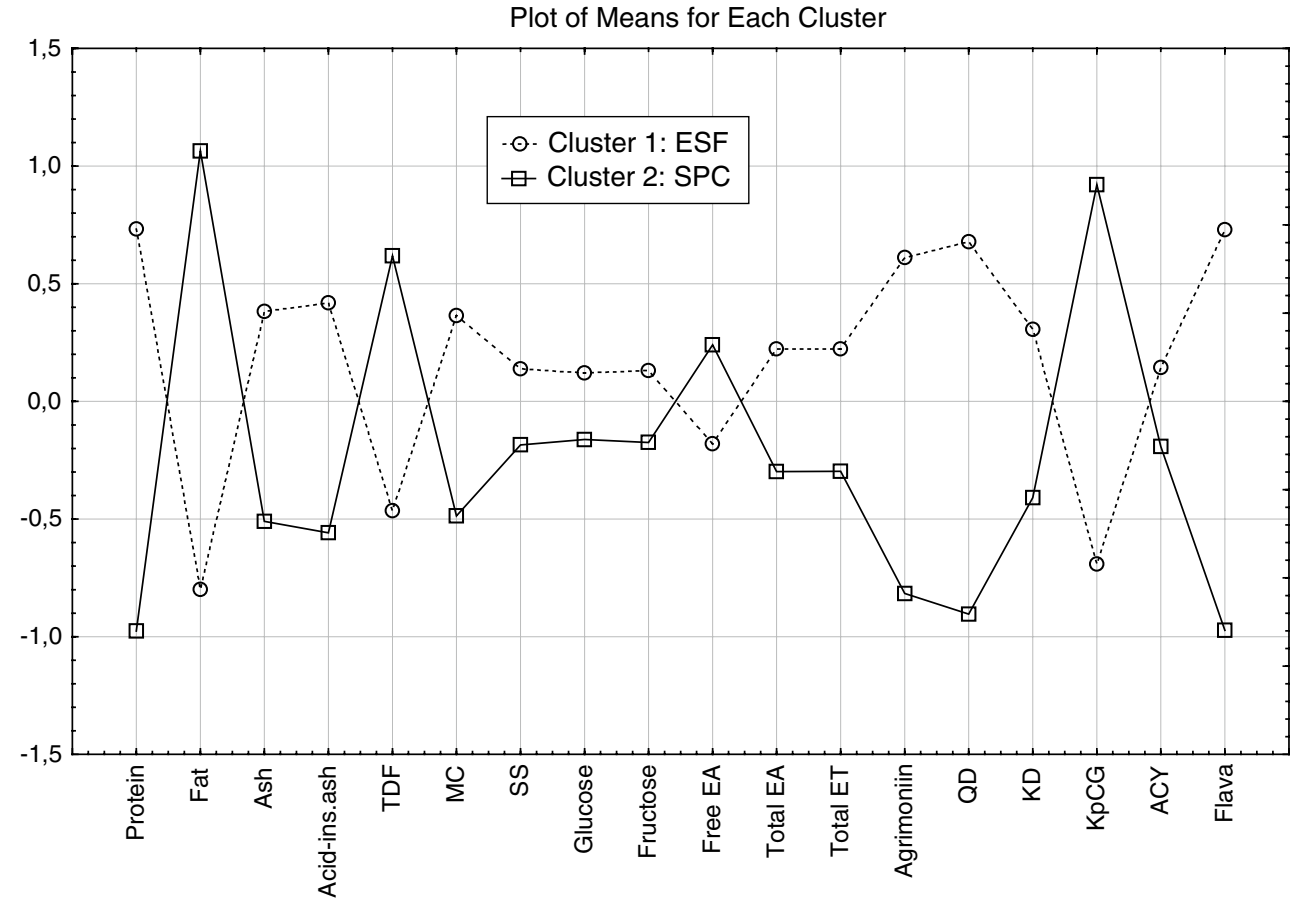


of polyphenols than whole press cake. The mean polyphenolic content of ESF is $5,400 \mathrm{mg} / 100 \mathrm{~g}$, as compared to $3,400 \mathrm{mg} / 100 \mathrm{~g}$ of SPC. Furthermore, the proanthocyanidin content of the seedless fraction is twice as high as that of whole press cake. It should be remembered that procyanidins constitute $69 \%$, and ellagitannins $28 \%$, of total ESF polyphenol content. Therefore, dried strawberry press cake, and especially its seedless fraction (ESF), despite sand contamination, should be recognized as a widely available and rich source of proanhocyanidins and most of all ellagitannins represented by agrimoniin.

Acknowledgments This study was financially supported by the Polish Ministry of Science and Higher Education as a part of the resources allocated for science in 2010-2013 under research project No. NN312360139.

The authors wish to express their gratefulness to prof. Anna Stochmal from Institute of Soil Science and Plant Cultivation at Puławy, Poland, for carrying the NMR analyses.

\section{Conflict of interest None.}

Compliance with Ethics Requirements This article does not contain any studies with human or animal subjects.

Open Access This article is distributed under the terms of the Creative Commons Attribution License which permits any use, distribution, and reproduction in any medium, provided the original author(s) and the source are credited.

\section{References}

1. Qin Y, Teixeira da Silva JA, Zhang L, Zhang S (2008) Transgenic strawberry: state of the art for improved traits. Biotechnol Adv 26:219-232

2. Giampieri F, Tulipani S, Alvarez-Suarez J, Quiles J, Mezzetti B, Battino M (2012) The strawberry: composition, nutritional quality, and impact on human health. Nutrition 28:9-19

3. FAOSTAT database (2012) http://faostat.fao.org. Accessed 10 January 2012

4. Oszmiański J, Wojdyło A, Kolniak J (2009) Effect of L-ascorbic acid, sugar, pectin and freeze-thaw treatment on polyphenol content of frozen strawberries. LWT-Food Sci Technol 42:581-586

5. Rissanen TH, Voutilainen S, Virtanen JK, Venho B, Vanharanta M, Mursu J, Salonen JT (2003) Low intake of fruits, berries and vegetables is associated with excess mortality in men: the kuopio ischaemic heart disease risk factor (KIHD) study. J Nutr 133(1):199-204

6. Lee ER, Kang GH, Cho SG (2007) Effect of flavonoids on human health: old subjects but new challenges. Recent Pat Biotechnol 1:139-150

7. Seeram NP, Lee R, Scheuller S, Heber D (2006) Identification of phenolic compounds in strawberries by liquid chromatography electrospray ionization mass spectroscopy. Food Chem 97:1-11

8. Matta-Riihinen K, Kamal-Eldin A, Torronen A (2004) Identification and quantification of phenolic compounds in berries of Fragaria and Rubus species (Family Rosaceae). J Agric Food Chem 52:6178-6187
9. Williner MR, Pirovani ME, Guemes DR (2003) Ellagic acid content in strawberries of different cultivars and ripening stages. J Sci Food Agric 83:842-845

10. Oszmiański J, Wojdyło A, Matuszewski P (2007) In polyphenols compounds changes in the industrial production process of concentrated strawberry juice. Żywność Nauka Technologia Jakość 1(50):94-104

11. Buendia B, Gil M, Tudela J, Gady A, Medina J, Soria C, Lopez J, Tomas-Barberan F (2010) HPLC-MS analysis of proanthocyanidin oligomers and other phenolics in 15 strawberry cultivars. $\mathrm{J}$ Agric Food Chem 58:396-3926

12. Pineli L, Moretti C, Santos MS, Campos AB, Brasileiro AV, Cordova AC, Chiarello MD (2011) Antioxidants and other chemical and physical characteristics of two strawberry cultivars at different ripeness stages. J Food Compos Anal 24:11-16

13. Odriozola-Serrano I, Soliva-Fortuny R, Martin-Belloso O (2008) Phenolic acids, flavonoids, vitamin $\mathrm{C}$ and antioxidant capacity of strawberry juices processed by high-intensity pulsed electric fields or heat treatments. Eur Food Res Technol 228:239-248

14. Vrhovsek U, Guella G, Gasperotti M, Pojer E, Zancato M, Mattivi F (2012) Clarifying the identity of the main ellagitannins in the fruit of the strawberry, Fragaria vesca and Fragaria ananassa Duch. J Agric Food Chem 60:2507-2516

15. Hukkanen AT, Kokko HI, Buchala AJ, McDougall GJ, Stewart D, Kärenlampi SO, Karjalainen RO (2007) Benzothiadiazole induces the accumulation of phenolics and improves resistance to powdery mildew in strawberries. J Agric Food Chem 55:1862-1870

16. Hanhineva K, Rogachev I, Kokko H, Mintz-Oron S, Venger I, Kärenlampi S, Aharoni A (2008) Non-targeted analysis of spatial metabolite composition in strawberry (Fragaria $x$ ananassa) flowers. Phytochemistry 69:2463-2481

17. Aaby K, Mazur S, Nes A, Skrede G (2012) Phenolic compounds in strawberry (Fragaria $\mathrm{x}$ ananassa Duch.) fruits: composition in 27 cultivars and changes during ripening. Food Chem 132:86-97

18. Ishimoto H, Shibata M, Myojin Y, Ito H, Sugimoto Y, Tai A, Hatano T (2011) In vivo anti-inflammatory and antioxidant properties of ellagitannin metabolite urolithin A. Bioorg Med Chem Lett 21:5901-5904

19. Maas J, Wang S, Galletta G (1991) Evaluation of strawberry cultivars for ellagic acid content. Hort Sci 26:66-68

20. Battino M, Beekwilder J, Denoyes-Rothan B, Laimer M, McDougall GJ, Mezzetti B (2009) Bioactive compounds in berries relevant to human health. Nutr Rev 67:145-150

21. Williams RJ, Spencer JPE, Rice-Evans C (2004) Flavonoids: Antioxidants or signalling molecules?

22. Balasundram N, Sundram K, Samman S (2006) Phenolic compounds in plant and agri-industrial by-products: antioxidant activity, occurrence and potential uses. Food Chem 99:191-203

23. Aaby K, Skrade G, Wrolstad RE (2005) Phenolic composition and antioxidant activities in flesh and achenes of strawberries. J Agric Food Chem 53:4032-4040

24. Kołodziejczyk K, Markowski J, Kosmala M, Król B, Płocharski W (2007) Apple pomace as a potential source of nutraceutical products. Pol J Food Nutr Sci. 57(4):291-295

25. Kosmala M, Kołodziejczyk K, Zduńczyk Z, Juśkiweicz J, Boros D (2011) Chemical composition of natural and polyphenol-free apple pomace and the effect of this dietary ingredient on intestinal fermentation and serum lipid parameters in rats. J Agric Food Chem 59:9177-9185

26. Aaby K, Wrolstad RE, Ekeberg D, Skrede G (2007) Polyphenol composition and antioxidant activity in strawberry purees; Impact of achene level and storage. J Agric Food Chem 55:5156-5166

27. Rój E, Dobrzyńska-Inger A, Kostrzewa D, Kołodziejczyk K, Sójka M, Król B, Miszczak A, Markowski J (2009) Extraction 
of berry seed oils with supercritical $\mathrm{CO}_{2}$. Przemysł Chemiczny 88(12):1325-1330

28. AOAC (1995) Method 920.152: protein in fruit products, Kjeldahl method. In: Official method of analysis, 16th edn. AOAC, Arlington

29. AOAC (1995) Method 930.09: ether extract of plants. In: Official method of analysis, 16th edn. AOAC, Arlington

30. AOAC (1995) Method 940.26: ash of fruits and fruit products. In: Official method of analysis, 16th edn. AOAC, Arlington

31. AOAC (1995) Method 941.12: ash of spices-gravimetric methods. In: Official method of analysis, 16th edn. AOAC, Arlington

32. AOAC (1995) Method 985.29: total dietary fiber in foods enzymatic-gravimetric method. In: Official method of analysis, 16th edn. AOAC, Arlington

33. ISO 2173:2003 Fruit and vegetable products-determination of soluble solids-refractometric method

34. Sójka M, Król B (2009) Composition of industrial seedless black currant pomace. Eur Food Res Technol 228:597-605

35. Klimczak E, Król B (2010) Determination of different forms of ellagic acid in by-products of strawberry processing. Zywn Technol Jakosc 4(71):81-94

36. Kennedy JA, Jones GP (2001) Analysis of proanthocyanidin cleavage products following acid-catalysis in the presence of excess phloroglucinol. J Agric Food Che 49:1740-1746

37. Elmadfa I, Muskat E (2003) Wielkie tabele kalorii i wartości odżywczych. Muza, Warszawa
38. Byszewski W (1972) Surowce roślinne. Państwowe Wydawnictwo Naukowe, Warszawa, pp 314-319

39. Pérez-Jiménez J, Torres JL (2011) Analysis of nonextractable phenolic compounds in foods: the current state of the art. J Agric Food Chem 59:12713-12724

40. Gu L, Kelm MA, Hammerstone JF, Beecher G, Holden J, Haytowitz D, Prior RL (2003) Screening of foods containing proanthocyanidins and their structural characterization using LC-MS/ MS and thiolytic degradation. J Agric Food Chem 51:7513-7521

41. Pinto M, Lajolo F, Genovese M (2008) Bioactive compounds and quantification of total ellagic acid in strawberries (Fragaria $x$ ananassa Duch.). Food Chem 107:1629-1635

42. Hakkinen S, Torronen AR (2000) Content of flavonols and selected phenolic acids in strawberries and Vaccinium species: influence of cultivar, cultivation site and technique. Food Res Int 33:517-524

43. Landete JM (2011) Ellagitannins, ellagic acid and their derived metabolites: a review about source, metabolism, functions and health. Food Res Int 44:1150-1160

44. Okuda Y, Yoshida T, Hatano T (2009) Ito H Ellagitannins renewed the concept of tannins In: Quideau S (ed) Chemistry and Biology of ellagitannins an underestimated class of bioactive plant polyphenols. World Scientific, Singapore 